\title{
Kemampuan Pemecahan Masalah Matematis Kelompok Matematika Ilmu Alam
} dan Ilmu-Ilmu Sosial

\author{
Holidun $^{1}$; Rubhan Masykur ${ }^{\text {; }}$ Suherman1; Fredi Ganda Putra1 \\ ${ }^{1}$ Jurusan Pendidikan Matematika, Universitas Islam Negeri Raden Intan Lampung. Jalan Endro \\ Suratmin, Sukarame, Bandar Lampung 35133, Indonesia. \\ *Corresponding Author. E-mail : kholidun99@gmail.com
}

Received: 19-12-2017; Revised: 06-01-2018; Accepted : 29-01-2018

\begin{abstract}
Abstrak
Tujuan penelitian ini adalah untuk mengetahui bagaimanakah kemampuan pemecahan masalah matematis peserta didik kelompok Matematika Ilmu Alam (MIA) dan Ilmu-ilmu Sosial (IIS) ditinjau dari minat belajar matematika peserta didik. Penelitian ini merupakan penelitian kualitatif berjenis analisis. Pengumpulan data dalam penelitian ini dilakukan dengan teknik triangulasi yang dilakukan pada saat peneliti menganalisis kemampuan pemecahan masalah matematis peserta didik. Teknik keabsahan data yang digunakan dalam penelitian ini adalah triangulasi teknik. Teknik analisis data yang digunakan adalah Model Miles dan Hubermen, yaitu reduksi data, penyajian data, dan penarikan kesimpulan. Hasil pembahasan menunjukkan peserta didik dengan kategori minat tinggi mampu menyelesaiakan pemecahan masalah dari tiap tahap-tahapan pemecahan masalah dengan benar. Peserta didik dengan kategori minat sedang dalam menyelesaikan masalah yang diberikan, mampu menyelsaiakan pemecahan masalah soal dan memenuhi semua indikator, namun dalam beberapa tahapan lainya masih kurang sistematis dalam penyelesaianya. Peserta didik dengan kategori minat rendah hanya mampu menyelesaiakan pada tahapan memahami masalah dan merencanakan masalah meskipun belum maksimal, dan belum mampu untuk menyelesaiakan tahapan lainnya.
\end{abstract}

Kata kunci: Analisis, pemecahan matematis, Minat belajar Matematika.

\begin{abstract}
The purpose of this study is to find out how the analysis of the mathematical problem-solving ability of students in Mathematics of Natural Sciences (MIA) and Social Sciences (IIS) groups in terms of interest in learning the mathematics of learners. This research is a qualitative research type analysis. The data collected in this research is done by a triangulation technique which is done when the researcher analyzes the problem-solving ability of mathematical learners. The technique of data validity used in this research is triangulation technique. Data analysis techniques used are Model Miles and Huberman, IE data reduction, data presentation, and conclusion. The results of the discussion show students with high-interest categories can solve the problem of each of the stages of problem-solving correctly. Students with moderate interest categories in solving the given problem, able to solve problem problems and meet all the indicators, but in some other stages are still less systematic in the settlement. Students with low-interest categories are only able to finish in the stages of understanding the problem and planning the problem, although not maximal yet, and have not been able to finish the other stages.
\end{abstract}

Keywords: Analysis, mathematical solving, Interests learning Math.

\section{PENDAHULUAN}

Pendidikan adalah hal yang terpenting dalam kehidupan seseorang merupakan salah satu faktor penting dalam pembangunan nasional, yang berfungsi sebagai upaya untuk meningkatkan kualitas hidup manusia
(Fuad, 2013). Di dunia pendidikan, matematika merupakan pelajaran yang memegang peranan penting dalam perkembangan ilmu pengetahuan dan teknologi (Hariyati \& Usodo, 2013). Peranan matematika sangat penting sebagai dasar logika atau penalaran dan 
penyelesaian kuantitatif yang dapat gunakan untuk pelajaran lainnya. Namun dalam perkembangannya, pembelajaran matematika di Indonesia belum memuaskan. Pada Ujian Nasional tahun 2015/2016 ternyata dari rata-rata nilai mata pelajaran matematika mempunyai rentang yang cukup jauh antara nilai tertinggi dan terrendah. Ini menjadi petunjuk kalau adanya kelemahan sekaligus kesulitan belajar dari peserta didik yang memperoleh nilai rendah tersebut. Hal ini menunjukkan bahwa banyak peserta didik mempunyai penguasaan yang kurang terhadap matematika. Merujuk dengan ungkapan tersebut dapat disimpulkan bahwa matematika merupakan pembelajaran yang kurang diminati oleh sebagian banyak peserta didik. Hal tersebut sesuai dengan hasil wawancara yang telah dilakukan oleh penuis kepada para peserta didik kelompok MIA maupun IIS bahwa banyak peserta didik yang mengalami kesulitan dalam memecahkan masalah-masalah yang ada dalam matematika, padahal pemecahan masalah pada pembelajaran matematika merupakan faktor yang penting karena merupakan kemampuan dasar yang harus dikuasai siswa.

Salah satu faktor kesulitan siswa dalam memecahkan masalah tidak terlepas dari model pembelajaran yang tidak sesuai dengan pembelajaran matematika (Wulandari, Mujib, \& Putra, 2016). Proses belajar mengajar di kelas dapat mempengaruhi mutu pendidikan(Irwandani \& Rofiah, 2015). Proses pembelajaran matematika yang monoton dan kurang kreatif, kadang membuat siswa sangat jenuh dan sangat bosan, hal ini biasanya menyebabkan siswa belajar dalam keaadan mengantuk, tidak konsentrasi, ramai sendiri yang mengakibatkan materi yang diajarkan tidak bisa diserap dengan baik oleh siswa. Hal tersebut sesuai dengan hasil wawancara terhadap guru matematika kelas XI bahwa dalam pembelajaran matematika guru hanya menggunakan metode ceramah dan drill saja, yang mana hal ini dikawatirkan penggunaan metode pembelajaran yang bermacam-macam membuat peserta didik kesulitan dalam menerima materi, tetapi pada kenyataannya penggunaan model pembelajaran tersebut yang dilakukan terus menerus membuat peserta didik pasif dalam bidang pengetahuan dan keterampilannya.

Kemampuan pemecahan masalah dalam pembelajaran matematika merupakan hal yang sangat penting untuk dikembangkan (Novianti, 2017; Yuliasari, 2017). Kemampuan ini sangat berguna bagi siswa pada saat mempelajari matematika maupun dalam kehidupan sehari-hari. Pemecahan masalah menjadi penting dalam tujuan pendidikan matematika disebabkan karena dalam kehidupan sehari hari manusia memang tidak pernah dapat lepas dari masalah. Selain itu aktivitas memecahkan masalah dapat dianggap suatu aktivitas dasar manusia. Setiap masalah harus dicari jalan keluarnya oleh manusia itu sendiri, jika tidak mau dikalahkan oleh kehidupan. Karena jika kemampuan pemecahan masalah sudah ada jalan keluarnya otomatis secara sendirinya akan berpengaruh pada minat belajar.

Minat belajar matematika menjadi faktor penting yang mempengaruhi penguasaan konsep matematika dalam memecahan masalah matematis. Minat sangat erat hubungannya dengan belajar, belajar tanpa minat akan terasa membosankan. Peserta didik yang berminat terhadap kegiatan belajar akan berusaha lebih keras dibandingkan peserta didik yang kurang berminat (Ikhsanudin, 2013). Minat yang tinggi terhadap suatu mata pelajaran, memungkinkan peserta didik memberikan perhatian yang tinggi terhadap mata pelajaran itu sehingga 
memungkinkan pula memiliki prestasi yang tinggi. Maka untuk mencapai prestasi yang tinggi, disamping kecerdasan, minat juga perlu ditingkatkan, sebab tanpa minat kegiatan belajar tidak akan efektif.

Memahami masalah-masalah di atas peneliti mencoba menganalisis kemampuan pemecahan masalah peserta didik dilihat dari minat belajar siswa. Kebaruan dalam penelitian ini akan menganalisis kemampuan pemecahan masalah siswa yang berasal dari kelompok ilmu pengetahuan alam dengan siswa yang berasal dari kelompok siswa ilmu-ilmu sosial.

\section{METODE}

Jenis penelitian ini adalah penelitian kualitaif, yaitu suatu penelitian yang ditujukan untuk mendeskripsikan dan menganalisis fenomena, peristiwa, aktivitas sosial, sikap, kepercayaan, persepsi, pemikiran orang secara individual maupun kelompok (Nana, 2010).

Penelitian ini menggambarkan atau mendeskripsikan kejadian-kejadian yang menjadi pusat perhatian (kemampuan pemecahan masalah, minat belajar peserta didik) secara kualitatif dan berdasarkan pada data kualitatif. Data yang dihasilkan nantinya berupa katakata atau ucapan-ucapan yang diperoleh dari hasil wawancara dan tulisan atau bilangan yang diperoleh dari hasil wawancara.
Berdasarkan pendekatan kualitatif dalam penelitian ini, semua fakta baik tulisan maupun lisan dari sumber data manusia yang telah diamati dan dokumen terkait lainnya yang diuraikan apa adanya kemudian dikaji seringkas mungkin untuk menjawab permasalahan. Teknik analisis data yang digunakan dalam penelitian ini adalah analisis data model Miles dan Huberman.

\section{HASIL DAN PEMBAHASAN}

Pemaparan hasil penelitian dilakukan secara terurut terhadap data hasil tes kemampuan pemecahan masalah matematis dari siswa kelas XI MIA dan IIS yang ditinjau dari minat belajar matematika. Setiap subyek masingmasing yang mewakili katagori tinggi, sedang, dan rendah dari minat belajar matematika. Selanjutnya di analisis bagaimanakah penyelesain peserta didik tersebut dalam menyelesaikan pemecahan masalah matematis. Data tersebut diuraikan menurut langkahlangkah pemecahan masalah matematis dari Polya yang meliputi memahami masalah, merencanakan penyelesaian, menjalakan rencana penyelesaian, mengecek kembali. Kemampuan pemecahan masalah ditinjau dari masingmasing langkah-langkah penyelesaian soal. Dari data yang terkumpul melalui angket minat belajar matematika menunjukan nilai yang dihasilkan cukup bervariasi.

\section{Tabel 1}

Deskriptif Data Minat Belajar Matematika Kelas XI Kelompok MIA 2

\begin{tabular}{ccccc} 
Minat Belajar & Tinggi & Sedang & Rendah & Jumlah \\
& Nilai $\geq \overline{\mathrm{x}}+\mathrm{SD}$ & $\overline{\mathrm{x}}-\mathrm{SD} \leq$ Nilai $<\overline{\mathrm{x}}+\mathrm{SD}$ & Nilai $<\overline{\mathrm{x}}-\mathrm{SD}$ & \\
Frekuensi & 8 & 17 & 5 & 30 \\
\hline
\end{tabular}

Berdasarkan Tabel 1, dari 30 jumlah peserta didik kelas XI kelompok MIA 2 diperoleh bahwa frekuensi dari kategori minat tertinggi ada 8 peserta didik, kemudian frekuensi untuk kategori minat sedang ada 17 peserta didik dan frekuensi kategori minat rendah ada 5 peserta didik. 
Desimal, 1 (1), 2018 - 32

Holidun; Rubhan Masykur; Suherman; Fredi Ganda Putra

Tabel 2.

Deskriptif Data Minat Belajar Matematika Kelas XI Kelompok IIS 1

\begin{tabular}{lcccc} 
Minat Belajar & Tinggi & Sedang & Rendah & Jumlah \\
& Nilai $\geq \overline{\mathrm{x}}+\mathrm{SD}$ & $\overline{\mathrm{x}}-\mathrm{SD} \leq$ Nilai $<\overline{\mathrm{x}}+\mathrm{SD}$ & Nilai $<\overline{\mathrm{x}}-\mathrm{SD}$ & \\
Frekuensi & 8 & 21 & 9 & 38 \\
\hline
\end{tabular}

Berdasarkan tabel 2., dari 38 jumlah peserta didik kelas XI kelompok IIS 1, diperoleh bahwa frekuensi dari kategori minat tertinggi ada 8 peserta didik, kemudian frekuensi untuk kategori minat sedang ada 21 peserta didik dan frekuensi kategori minat rendah ada 9 peserta didik.

Pemecahan masalah matematis merupakan pemecahan masalah yang memerlukan tahap-tahap atau langkahlangkah yang dilakukan siswa secara sistematis. Berdasarkan hasil tes angket yang diberikan kepada kelas XI MIA 2 dan IIS 1, dari kelas MIA 2 terdapat 30 jumlah peserta didik diperoleh masing-masing kategori minat tertinggi ada 8 peserta didik, kemudian untuk kategori minat sedang ada 17 peserta didik dan kategori minat rendah ada 5 peserta didik. Sedangkan dari kelas XI IIS 1, terdapat 38 jumlah peserta didik diperoleh masingmasing kategori minat tertinggi ada 8 peserta didik, kemudian untuk kategori minat sedang ada 21 peserta didik dan kategori minat rendah ada 9 peserta didik. Pengelompokan peserta didik kedalam masing-masing kategori minat didasarkan pada perolehan skor masingmasing. Selanjutnya dipilih 3 siswa dari kelas XI MIA 2 dan 3 siswa dari kelas XI IIS 1 untuk mewakili masing-masing kategori minat. Adapun pembahasan dari setiap subyek dapat dinyatakan sebagai berikut:

\section{Kemampuan yang diperoleh subyek H1}

Berdasarkan hasil penelitian diperoleh bahwa, dalam memecahkan masalah tahap pertama subyek H1 sudah memiliki motivasi untuk menyelesaiakan. Dalam mendefinisikan, siswa mampu memahami soal dengan baik, mengetahui dengan tepat informasi yang ada dalam soal. Subyek H1 dalam tahap merencanakan masih terdapat kekurangan, siswa cenderung bingung dan salah untuk menentukan simbol dari nialai optimum. Dalam mengerjakan, subyek H1 menyelesaiakan masalah dengan tahapan dan proses perhitungan yang benar. Subyek H1 dalam tahapan melihat kembali jawaban mampu memeriksa hasil penyelesaian dengan benar. Berdasarkan pembahasan tersebut, siswa pada kategori minat tinggi diketahui bahwa pada tahapan merencanakan masih terdapat kekurangan dibandingkan tahap pemecahan yang lain.

Berdasarkan indikator kemampuan pemecahan masalah matematis peserta didik $\mathrm{H} 1$ dalam menyelesaiakan masalah matematika berdasarkan teori Polya yaitu: peserta didik $\mathrm{H} 1$ dapat memahi masalah, merencanakan penyelesaian: menyelesaiakan penyelesaian, dan mengecek kembali, tetapi proses yang dilakukan peserta didik masih kurang maksimal.

Hasil penelitian yang dilakukan oleh Rofikoh tahun 2015 menunjukan bahwa pemecahan masalah (Problem Solving) merupakan suatu proses yang masih sulit bagi siswa salah satunya pada tahap merencanakan masalah, sehingga tidak semua soal dapat diselesaikan dengan baik (Rofiqoh, 2015). Sejalan dengan penelitian Rofiqoh, dalam tahap penyelesaian masalah ini, peserta didik melakukan proses tahap-tahapan yang benar namun masih kurang maksimal 
Desimal, 1 (1), 2018 - 33

Holidun; Rubhan Masykur; Suherman; Fredi Ganda Putra

meskipun hasil yang diperoleh dari soal itu benar.

\section{Kemampuan yang diperoleh subyek $\mathrm{H} 2$}

Berdasarkan hasil penelitian diperoleh bahwa, dalam memecahkan masalah tahap pertama subyek $\mathrm{H} 2$ sudah memilki motivasi untuk menyelesaikan permasalahan dalam soal. Dalam merencanakan masalah, siswa belum bisa menyebutkan apa informasi yang diketahui dengan lengkap. Subyek H2 dalam melaksanakan penyelesaian masih banyak kekurangan belum menggunakan langkah yang tepat dan sistematis untuk mendapatkan hasilnya. Subyek $\mathrm{H} 2$ dalam tahap melihat kembali jawaban pada nomor 1 masih kurang yakin dan pada soal nomor 2 siswa tidak menuliskan apapu. Berdasarkan pembahasan tersebut, siswa pada kategori minat sedang hanya mampu untuk mengerjakan tetapi kurang maksimal untuk langkahlangkah yang lain.

Berdasarkan indikator kemampuan pemecahan masalah matematis peserta didik $\mathrm{H} 2$ dalam menyelesaiakan masalah matematika berdasarkan teori Polya yaitu: peserta didik $\mathrm{H} 2$ dapat memahi masalah, merencanakan penyelesaian, menyelesaiakan penyelesaian, dan mengecek kembali, tetapi proses yang dilakukan peserta didik masih kurang sistematis. Hasil yang sama dengan penelitian oleh Zeni Rofikoh pada tahun 2015 mengungkapkan bahwa respon siswa pada tahap menyelsaikan masalah: peserta didik menuliskan hasil penyelesaian permasalahan soal matematika yang diberikan dengan benar namun masih ada yang salah pada tahaptahap lainya, sehingga tidak dapat memberikan hasil penyelesaian yang sistematis.

\section{Kemampuan yang diperoleh subyek H3}

Berdasarkan hasil penelitian diperoleh bahwa, dalam memecahkan masalah tahap pertama subyek H3 memilki motivasi untuk menyelesaikan permasalahan dalam soal. Dalam memahami dan merencanakan siswa belum bisa menyebutkan apa informasih yang diketahui dalam soal dengan tepat. Subyek H3 dalam melaksanakan penyelesaian siswa tidak mampu menyelesaiakanya masalah dalam soal. Dalam tahap melihat kembali jawaban siswa tidak menuliskan apapun. Berdasarkan pembahasan tersebut, siswa pada kategori minat rendah hanya memiliki motivasi tetapi kurangnya pengetahuan untuk tahap-tahap yang lain. Berdasarkan indikator kemampuan pemecahan masalah matematis peserta didik H3 dalam menyelesaiakan masalah matematika berdasarkan teori Polya yaitu: peserta didik H3 hanya mampu menyelesaiakan pada tahap memahami masalah, dan peserta didik $\mathrm{H} 3$ belum mampu untuk menyelesaiakan tahaptahapan lainya.

\section{Kemampuan yang diperoleh subyek T1}

Berdasarkan hasil penelitian diperoleh bahwa, dalam memecahkan masalah tahap pertama subyek T1 sudah memiliki motivasi untuk menyelesaiakan. Dalam mendefinisikan, siswa mampu memahami soal dengan baik, mengetahui dengan tepat informasi yang ada dalam soal. Subyek T1 dalam tahap merencanakan masih terdapat kekurangan, siswa cenderung bingung dan salah untuk menentukan simbol dari nialai optimum. Dalam mengerjakan, subyek T1 menyelesaiakan masalah dengan tahapan dan proses perhitungan yang benar. Subyek T1 dalam tahapan melihat kembali jawaban mampu 
memeriksa hasil penyelesaian dengan benar. Berdasarkan pembahasan tersebut, siswa pada kategori minat tinggi diketahui bahwa pada tahapan merencanakan masih terdapat kekurangan dibandingkan tahap pemecahan yang lain.

Berdasarkan indikator kemampuan pemecahan masalah matematis peserta didik T1 dalam menyelesaiakan masalah matematika berdasarkan teori Polya yaitu: peserta didik T1 dapat memahi masalah, merencanakan penyelesaian: menyelesaiakan penyelesaian, dan mengecek kembali, tetapi proses yang dilakukan peserta didik masih kurang maksimal.

Hasil penelitian yang dilakukan oleh Zeni Rofikoh tahun 2015 menunjukan bahwa pemecahan masalah (Problem Solving) merupakan suatu proses yang masih sulit bagi siswa salah satunya pada tahap merencanakan masalah, sehingga tidak semua soal dapat diselsaikan dengan baik. Sejalan dengan penelitian (Zeni Rofikoh 2015) dalam tahap penyelesaian masalah ini, peserta didik melakukan proses tahap-tahapan yang benar namun masih kurang maksimal meskipun hasil yang diperoleh dari soal itu benar.

\section{Kemampuan yang diperoleh subyek T2}

Berdasarkan hasil penelitian diperoleh bahwa, dalam memecahkan masalah tahap pertama subyek T2 sudah memilki motivasi untuk menyelesaikan permasalahan dalam soal. Dalam merencanakan masalah, siswa belum bisa menentukan titik koordinat dari tiap pertidaksamaan dalam soal. Subyek T2 dalam melaksanakan penyelesaian masih banyak kekurangan belum menggunakan langkah yang tepat dan sistematis untuk mendapatkan hasilnya. Subyek T2 dalam tahap melihat kembali jawaban pada nomor 1 masih kurang yakin dan pada soal nomor 2 siswa tidak menuliskan apapun. Berdasarkan pembahasan tersebut, siswa pada kategori minat sedang hanya mampu untuk mengerjakan tetapi kurang maksimal untuk langkahlangkah yang lain.

Berdasarkan indikator kemampuan pemecahan masalah matematis peserta didik T2 dalam menyelesaiakan masalah matematika berdasarkan teori Polya yaitu: peserta didik T2 dapat memahi masalah, merencanakan penyelesaian, menyelesaikan penyelesaian, dan mengecek kembali, tetapi proses yang dilakukan peserta didik masih kurang sistematis. Hasil yang sama dengan penelitian oleh Zeni Rofikoh pada tahun 2015 mengungkapkan bahwa respon siswa pada tahap menyelsaikan masalah: peserta didik T2 menuliskan hasil penyelesaian permasalahan soal matematika yang diberikan dengan benar namun masih ada yang salah pada tahaptahap lainya, sehingga tidak dapat memberikan hasil penyelesaian yang sistematis.

\section{Kemampuan yang diperoleh subyek T3}

Berdasarkan hasil penelitian diperoleh bahwa, dalam memecahkan masalah tahap pertama subyek T3 memilki motivasi untuk menyelesaikan permasalahan dalam soal. Dalam memahami dan merencanakan siswa belum bisa menyebutkan apa informasih yang diketahui dalam soal dengan tepat. Subyek T3 dalam melaksanakan penyelesaian siswa tidak mampu menyelesaiakanya masalah dalam soal. Dalam tahap melihat kembali jawaban siswa tidak menuliskan apapun. Berdasarkan pembahasan tersebut, siswa pada kategori minat rendah hanya memiliki motivasi tetapi kurangnya pengetahuan untuk tahap-tahap yang lain. 
Berdasarkan indikator kemampuan pemecahan masalah matematis peserta didik $\mathrm{H} 3$ dalam menyelesaiakan masalah matematika berdasarkan teori Polya yaitu: peserta didik H3 hanya mampu menyelesaiakan pada tahap memahami masalah, dan peserta didik $\mathrm{H} 3$ belum mampu untuk menyelesaiakan tahaptahapan lainya.

Pada penelitian ini juga terdapat temuan baru bahwa dari hasil triangulasi pekerjaan siswa dan wawancara dapat disimpulkan bahwa tahap yang paling banyak terdapat kesalahan adalah pada saat tahap merencanakan masalah dimana peserta didik harus membuat model matematika dan menentukan titik perpotongan persamaan dari soal program linear. Sedangkan tahap mudah diselesaikan oleh subyek adalah pada tahap memahami masalah dimana siswa hanya memisalkan varibel $\mathrm{x}$ dan $\mathrm{y}$ dari permasalah soal program linear. Salah satu solusi untuk memeperbaiki pemhaman siswa dari permasalahan ini yaitu pendidik harus memberikan perhatian yang lebih kepada siswa ketika proses pembelajaran, menggunakan strategi pembelajaran yang baik sehingga materi yang disampaikan mudah di pahami oleh peserta didik, mewajibkan siswa untuk proaktif ketika proses pemebelajaran berlangsung dan memberikan banyak latihan soal yang harus dikerjakan oleh siswa agar pemahaman siswa lebih meningkat salah satunya pada tahapan merencanakan masalah.

\section{SIMPULAN DAN SARAN}

Berdasarkan hasil analisis data dan pembahasan dari pemecahan masalah matematis siswa kelas XI MIA 2 dan IIS 1 yang ditinjau dari minat belajar matematika dapat disimpulkan bahwa peserta didik dengan minat tinggi, sedang, dan rendah memiliki kemampuan penyelesaian soal dari tiap tahapan indikator penyelesaian masalah yang berbeda-beda. Peserta didik dengan kategori minat tinggi memenuhi semua indikator tahapan penyelesaian masalah, dari memahami masalah, merencanakan masalah, menyelesaikan masalah, dan mengecek kembali. Peserta didik mampu menyelesaiakan ke empat tahapan indikator tersebut dari permasalahan soal yang diberikan. Maka dapat disimpulkan bahwa peserta didik dengan kategori minat tinggi mampu menyelesaiakan pemecahan masalah dari tiap tahaptahapan pemecahan masalah dengan benar.

Peserta didik dengan kategori minat sedang dalam menyelesaikan masalah yang diberikan, mampu menyelsaiakan pemecahan masalah soal dan memenuhi semua indikator, namun dalam beberapa tahapan lainya masih kurang sistematis dalam penyelesaianya. Maka dapat disimpulkan bahwa peserta didik dengan kategori minat sedang mampu menyelesaiakan pemecahan masalah dari tiap tahap-tahapan pemecahan masalah, tetapi belum sistematis dan maksimal. Berbeda dengan peserta didik dengan kategori minat rendah, yang dapat dilihat dari keterpenuhan indikator minat belajar matematika, peserta didik dengan kategori minat rendah hanya mampu menyelesaiakan pada tahapan memahami masalah dan merencanakan masalah meskipun belum maksimal, dan peserta didik minat rendah belum mampu untuk menyelesaiakan tahapan lainya. Maka dapat disimpulkan bahwa peserta didik dengan kategori minat rendah belum mampu menyelesaiakan pemecahan masalah dari tiap tahap-tahapan pemecahan masalah dengan benar. Namun peserta didik dengan kategori minat rendah sudah memiliki motivasi dan keyakinan untuk mengerjakan soal yang diberikan.

Kemampuan penyelesaian pemecahan matematis peserta didik yang ditinjau dari minat belajar matematika 
masih banyak mengalami hambatan. Adapun hambatan yang mengakibatkan peserta didik belum mampu memberikan hasil secara maksimal jika dilihat dari indikator pemechan masalah matematis: (1) peserta didik belum mampu menuangkan langkah penyelesaian matematika yang berbentuk soal cerita dengan baik ke dalam model penyelesaian matematika; (2) peserta didik belum maksimal dalam meyelesaikan masalah pada tahapan merencankan masalah;

peserta didik belum terbiasa meninjau ulang kembali jawaban yang telah dikerjakan.

Bagi guru dengan mengetahui kemampuan pemecahan masalah matematis dari tiap peserta didik dan untuk meningkatkan pemaham kemampuan pemecahan masalah matematis peserta didik, guru dapat menggunakan strategi pembelajaran yang lebih baik sehingga materi yang disampaikan mudah di pahami oleh peserta didik, mewajibkan siswa untuk proaktif ketika proses pemebelajaran berlangsung dan memberikan banyak latihan soal yang harus dikerjakan oleh siswa agar pemahaman siswa lebih meningkat.

\section{DAFTAR PUSTAKA}

Fuad, I. (2013). Dasar-dasar Pendidikan. Jakarta: Rineka Cipta.

Hariyati, E., \& Usodo, B. (2013). Efektivitas Model Pembelajaran Kooperatif Tipe Team Assisted Individualization (TAI) dan Problem Based Learning (PBL) Pada Prestasi Belajar Matematika Ditinjau Dari Multiple Intelligences Siswa SMP Kabupaten Lampung Timur Tahun Pelajaran 2012/2013. Jurnal Pembelajaran Matematika, 1(7).

Ikhsanudin, I. (2013). Pengaruh Penggunaan Pembelajaran Kooperatif Tipe STAD Berbantuan Wingeom Terhadap Kemampuan
Pemecahan Masalah Geometri Siswa SMA (PhD Thesis). Universitas Terbuka.

Irwandani, I., \& Rofiah, S. (2015). Pengaruh Model Pembelajaran Generatif Terhadap Pemahaman Konsep Fisika Pokok Bahasan Bunyi Peserta Didik MTs Al-Hikmah Bandar Lampung. Jurnal Ilmiah Pendidikan Fisika Al-Biruni, 4(2), 165-177. https://doi.org/10.24042/jpifalbiru ni.v4i2.90

Nana, S. (2010). Metode Penelitian Pendidikan. Bandung: Remaja Rosdakarya.

Novianti, D. E. (2017). Profil Pemecahan Masalah Matematika Dalam Menyelesaikan Permasalahan Pemrograman Linear Ditinjau Dari Kemampuan Komunikasi Matematis Mahasiswa. JIPM Uurnal Ilmiah Pendidikan Matematika), 6(1), 5359.

Putra, F. G. (2017). Eksperimentasi Pendekatan Kontekstual Berbantuan Hands On Activity (HoA) Terhadap Kemampuan Pemecahan Masalah Matematik. Al-Jabar: Jurnal Pendidikan Matematika, 8(1), 73-80. https://doi.org/10.24042/ajpm.v8i1 .1148

Rofiqoh, Z. (2015). Analisis kemampuan pemecahan masalah matematika siswa kelas $x$ dalam pembelajaran discovery learning berdasarkan gaya belajar siswa (PhD Thesis). UNIVERSITAS NEGERI SEMARANG.

Wulandari, P., Mujib, M., \& Putra, F. G. (2016). Pengaruh Model Pembelajaran Investigasi Kelompok berbantuan Perangkat Lunak Maple terhadap Kemampuan Pemecahan Masalah Matematis. Al-Jabar: Jurnal Pendidikan Matematika, 7(1), 101106.

Yuliasari, E. (2017). Eksperimentasi Model PBL dan Model GDL Terhadap Kemampuan Pemecahan Masalah Matematis Ditinjau dari Kemandirian 
Desimal, 1 (1), 2018 - 37

Holidun; Rubhan Masykur; Suherman; Fredi Ganda Putra

Belajar. JIPM Jurnal Ilmiah

Pendidikan Matematika), 6(1), 1-10. 